\title{
COLONIAL INSTITUTIONALISATION OF POVERTY AMONG BLACKS IN SOUTH AFRICA
}

\author{
Tshepo Lephakga \\ Department of Philosophy, Practical and Systematic Theology \\ University of South Africa \\ lephat@unisa.ac.za
}

\section{ABSTRACT}

This article examines colonial institutionalisation of poverty amongst colonised and conquered blacks in South Africa. Colonialism divided the world in two: the centre, which is occupied by Europeans, and the periphery, which is occupied by non-Europeans. This division institutionalised poverty amongst the colonised to maintain the supremacist status of the coloniser and the colonial status of the colonised as non-beings. Colonial apartheid, following the colonial epistemological foundation(s) and justification(s) of the centre imposing itself on the periphery, strived to make black people go through social death, which became a necessity fed into the colonial thinking that those in the periphery are lesser beings. Social death was engineered and maintained through the impoverishment of black people. Poverty and colonial dependency syndrome were institutionalised following the systematic institutionalisation of the social creation of race. A number of scholars have noted that race is a social creation with real consequences. It is thus not surprising that the painful history of South Africa resulted in the impoverishment of the majority of the people in the country. Following its long historical institutionalisation, poverty resulted in poor black people internalising oppression and doubting their humanness. This paper contends that colonial apartheid is the cause of a vast inequality in the South African society, including social institutionalised poverty among the blacks in South Africa.

Keywords: Poverty; colonialism; institutionalisation; economy; conquering; social death; transition; neo-liberal transition

\section{INTRODUCTION}

The negotiated settlement in South Africa brought with it a number of expectations (Lephakga 2015, 95-148), including an end to institutionalised poverty among the blacks in South Africa, their inclusion in the main economy and their reconciliation with their black selfhood, which was alienated as a result of the long, systematic institutionalisation

\section{UNISA $\approx$}

Studia Historiae Ecclesiasticae https://upjournals.co.za/index.php/SHE
DOI: http://dx.doi.org/10.17159/2412-4265/2016/1273 Print ISSN 1017-0499 | Online 2412-4265

(C) 2016 The Author(s) 
of social death among them (Lephakga 2015, 95-148; Stevens, Franchi and Swart 2006, 293-312; Terreblanche 2002, 51-89). However, these expectations were watershed by contradictory legacies which the democratically elected government inherited (Bond 2000, L1139, 39-93; Stevens et al 2006, 293-312; Terreblanche 2002, 25-47). These contradictory legacies included the following:

- The most developed economy in Africa, but also major socio-economic problems (Bond 2000, 11-39, 39-64; Stevens et al 2006, 293-312; Terreblanche 2002, 1618, 371-406).

- The highest rates of unemployment.

- Abject poverty among the black (conquered) people.

- Sharp inequalities in the distribution of income, property and opportunities.

- High levels of crime and violence. (Terreblanche 2002, 25)

Terreblanche $(2002,27)$ correctly notes in relation to the transition that "this transition has been hailed worldwide as a political miracle". Furthermore, Terreblanche notes that this "political miracle" can be attributed largely to Nelson Mandela and his reconciliatory attitude, which led to the peaceful transition to a non-racial dispensation in which humanity and the dignity of all South Africans are protected in a constitutional democracy. However, Terreblanche $(2002,25-27)$ notes that this celebrated political miracle is watershed by both the inherited contradictory legacies and the fact that the political transformation did not translate to socio-economic transformation.

Terreblanche $(2002,27)$ further points to a matter of grave concern: "[I]t should be remembered that the transition to democracy unleashed pent-up expectations of a restoration of social justice and a dramatic improvement in the living conditions of blacks." These contradictory inherited legacies were worsened by what Lephakga (2015, 95-148) calls the "neo-liberal transition to democracy under capitalism". This transition is characterised by a transition to a dual politico-economic system which espouses the contradictory principles of democracy and capitalism (Lephakga 2015; Terreblanche 2002). It espouses a just and principled emphasis on joint interests, equality and inclusion on the one hand, with self-seeking inequality and conflicting individual and group interests on the other hand (Bond 2000, 11-38, 39-64; Lephakga 2015, 95-148; Terreblanche 2002, 16-18).

The transition is further worsened by the fact that these contradictory principles, which were emphasised by both democracy and capitalism, are protected by the legal principle of "equality before the law" (Terreblanche 2002, 16). In this context this legal principle is problematic because legal empowerment does not necessarily translate into socio-economic empowerment (Lephakga 2015, 95-148; Mamdani 2006, 5; Terreblanche 2002, 16-18).

On the one hand the legal principle of "equality before the law" seems to dehistoricise the notion of "equality" within South Africa, which must be engaged in relation to the notion of humanity. This is because for a long time blacks in South Africa followed the 
logic of colonisation which divided the world into two, ${ }^{1}$ namely the centre (occupied by Europeans) and the periphery (occupied by non-Europeans) (Dussel 1985, 1-9; Fanon 1963, 38-42; Lephakga 2015, 145-147). Black people were legally alienated (Biko 2004, 98-106; Pheko 1986) and relegated to the state of social death - that is the social condition of people (in this context the colonised/conquered) not being accepted as fully human by the wider society (in this context the coloniser/conqueror) (Patterson 1982); they were relegated to lesser beings ${ }^{2}$ (Fanon 1963, 38-42). As a result of this institutionalised alienation, black people were relegated to the state of institutionalised poverty and thus dependence upon their colonisers/conquerors for their survival (Biko 2004, 88-95, 96-108).

On the other hand the legal principle of "equality before the law" seems to promote socio-economic tabula rasa (blank slate) because it seems to suggest that suddenly, without historical consideration, "we are all equal" before the law and thus can participate in for instance the economy of South Africa (Lephakga 2015, 95-148; Terreblanche 2002, 16-18). However, this legal principle fails to take into consideration the historical institutionalisation of inequalities between black people (who happen to be the historical conquered nation) and white people (who happen to be the historical conquering nation). This legal principle also fails to notice that under capitalism, which promotes the principle of competition, one needs to have assets in order to participate in the economy; given the history of South Africa, black people do not have assets and therefore cannot participate and are still excluded (Lephakga 2015, 95-148; Terreblanche 2002, 16-18, 371-406).

This paper, therefore, argues that poverty was institutionalised (Pheko 1986, 1-92; Terreblanche 2002, 25-46) to justify the narrative created through colonisation of the periphery by the centre, that black people are not fully human and thus are dependent upon their colonisers/conquerors for their survival (Dussel 1985, 1-9; Lephakga

1 Tshepo Lephakga, in his paper titled "The history of the Conquering of the Being of Africans through Land Dispossession, Epistemicide and Proselytization" (2015) expands the Dusselian (Dussel 1985, 1-9) notion of the division of the world into two - that is, between the centre (which is occupied by Europeans who assume the status of being the super-Beings) and the Periphery (which is occupied by non-Europeans who are relegated to the status of non-beings). This division gave justification for colonisation. This is because the centre felt justified to impose itself on the periphery (Lephakga 2015, 145-163).

2 Tshepo Lephakga, in his paper titled "The history of the Conquering of the Being of Africans through Land Dispossession, Epistemicide and Proselytization" (2015) makes the Dusselian (1985) and Fanonian (1963) distinction between the Being (that is the idea of being in the world - and also includes both the Heideggerian notions of presence and existence) (with Capital letter B) and the being (with the small letter b). This is an informed idea that Europeans, following their extrapolation of the Greek hierarchy of beings who make up the state have divided the world into two - namely between the centre (which Fanon calls the zone of Being) which is occupied by Europeans who have assumed the status of Being (with the capital letter B) and the periphery (which Fanon calls the zone of non-being) which is occupied by non-Europeans who have been relegated to the status of being (with the small letter b) or status of non-being (Dussel 1985; Fanon 1963; Lephakga 2015; Maldonado-Torres 2007). 
2015, 95-148). Terreblanche $(2002,25-26)$ rightly notes that "we cannot avoid the conclusion that unemployment, poverty, inequality, violence, and criminality are not only serious problems that mainly affect black South Africans, but also that they have an indisputable structural or systematic character". For this reason, when colonial apartheid was legalised, a number of unethical (although then legally) acts (for instance: The Reservation of Separate Amenities Act of 1953; The Natives Building Workers Act of 1951; The Bantu Education Act of 1953; The Prohibition of Mixed Marriages Act of 1949; The Immorality Amendment Act of 1950; The Group Areas Act of 1950; The Native Laws Amendment Act of 1952; The Promotion of Bantu Self-government Act of 1959 - to name a few) were passed in order to alienate and dispossess black people from their black selves and from their country of birth (Biko 2004, 88-95; Lephakga 2012b; 2013; Pheko 1986, 1-92; Terreblanche 2002, 3-21) and to restrict them to areas which would guarantee their exclusion from the main economy and thus relegate them to the status of not only being less human but also poor (Biko 2004, 96-108, 88-95; Lephakga 2012b, 65-80; 2013, 379-400; 2015, 145-148; Pheko 1986, 1-92; Terreblanche 2002, $371-406)$. Thus Terreblanche $(2002,25)$ rightly notes that:

[M] ost unemployed people [in South Africa] are Africans; more Africans than any others live in abject poverty; the inequalities in the distribution of income, poverty and opportunities are mainly to the detriment of Africans; and it is largely Africans who are criminalised during the long periods of repression, discrimination, and violence, and who are now the main victims of criminality and violence.

It is for this reason that this paper will look into the following: (1) Colonial apartheid's social institutionalisation of poverty amongst blacks; (2) Neo-liberal transition to democracy and its maintenance of poverty amongst blacks; and (3) Conclusion.

\section{COLONIAL APARTHEID'S SOCIAL INSTITUTIONALISATION OF POVERTY AMONG BLACKS}

Poverty $^{3}$ among black people in South Africa was socially engineered and institutionalised to maintain social death among the colonised and conquered (Asante and Hall 2011; Biko 2004, 96-108; Dussel 1985, 1-9; Fanon 1963, 38-42; Lephakga 2015; Patterson 1982, 1-77; Pheko 1986, 1-92; Terreblanche 2002, 25-46). According to the colonial epistemological foundations and justifications those who were colonised and conquered were non-beings occupying a peripheral zone (Biko 2004; Dussel 1985, 1-9; Fanon 1963, 38-42; Lephakga 2015, 95-148; Mudimbe 1988). Thus, it must be kept in mind that, as Dussel (1985, 1-9) and Mudimbe (1988, 1-23) note, the epistemological foundation and justification of colonisation were built on the division of the world

3 Following Terreblanche (2002), Fanon (1963), Biko (2004) and Dussel (1985), poverty is defined as a systematic and structural state of being alienated from material possession(s). 
by Europeans into the centre and the periphery. According to these epistemological foundations and justifications of colonisation, the centre is occupied by Europeans who are Beings (with the capital B) and the periphery is occupied by non-Europeans who are non-beings (Dussel 1985, 1-9; Fanon 1963, 38-42; Lephakga 2015, 95-148; Mudimbe 1988, 1-23; Ramose 1999, 541-589). This division of the world in two, follows or was influenced by the Greeks' construction of Beings who made up society or the state. The Greeks divided beings into a hierarchy of men from noble families, children from noble families, women and slaves (Aristotle in Sinclair 1962, 25-40; Dussel 1985, 1-9; Kitto 1951, 7-121; Ramose 1999, 541-589). The epistemological foundation of this construction of beings was that men who were born from noble families and whose intellect overpowered their emotions, were by virtue Beings (Aristotle in Sinclair 1962, 25-40; Dussel 1985, 1-9; Kitto 1951, 7-12; Lephakga 2015, 145-163; Ramose 1999, 541-589). While children from noble families had an opportunity, given their noble background, to be Beings, women and slaves were regarded as non-beings. However, slaves were distinguished from women in that women, as a result of their proximity to their noble man, were not like slaves. Slaves, on the other hand, were not from noble families and as a result of their proximity to their non-noble family background they could not assume the status of Beings like those from noble families (Aristotle in Sinclair 1962, 25-40; Dussel 1985, 1-9; Kitto 1951, 7-12; Lephakga 2015, 145163; Ramose 1999, 541-589). As a result of this construction of beings who made up society or the state, it was upon men from noble families, who were Beings, to be the guardians of children, women and slaves (Aristotle in Sinclair 1962, 25-40; Dussel 1985, 1-9; Kitto 1951, 7-12; Lephakga 2015, 145-163; Ramose 1999, 541-589). This epistemological foundation (of both the Greeks and the Europeans) gave justification to colonisation of the periphery by the centre. Thus, this paper argues that the history of colonial apartheid must be viewed as a continuation of a historically institutionalised imposition of the centre (Europeans) on the periphery (non-Europeans). On the one hand this was done in order to maintain the centre (and its European occupants), or what Fanon $(1963,29-33)$ calls the settlers' town. On the other hand it was done, in line with the colonial epistemological foundation, to impoverish the colonised and conquered to create dependency. The (European) centre or the coloniser was a continual guardian to the (non-European) periphery or the colonised and conquered.

Given the above, it is argued in this paper that the painful history of colonial apartheid in South Africa resulted in the institutionalised impoverishment of mainly blacks, who happened to be the colonised and a conquered nation ${ }^{4}$ (Pheko 1986, 1-92; Terreblanche 2002, 371-400). The system of colonial apartheid, which was legally and officially entrenched in 1948 after the National Party came into power, had a terrible impact upon the conquered blacks (Lephakga 2013, 379-400; 2015, 95-148). The colonial apartheid

4 Mudimbe (1988:1) notes that, the notion of colonisation (which is used interchangeably with the notion of conquering) involves the idea of (re-) organising and (re-) arranging colonies as satellites of colonial countries. 
system was based on the social creation of racial segregation (that is to say that race is not real but is socially constructed) and discrimination (Lembede 1996; Sobukwe 1959), which was a continuation of the historical colonial epistemological foundation(s) and justification(s) of colonisation. This racial social creation was engineered to further offer epistemological foundation(s) and justification(s) to the colonial epistemology, which claimed, and eventually institutionalised the thinking, that blacks, as per the colonial division of the world, occupy the periphery, which is a zone of non-beings. As a result of this, then, the social creation of race was engineered to institutionalise the supremacy of those who occupy the centre, which is a zone of Beings (Fanon 1963, 38-42; Lephakga 2015, 36-93).

It must be mentioned, however, that the consequences of this institutionalised racial social creation are real (Biko 2004, 96-108; Fanon 1963, 38-42). Thus, it is argued in this paper that the system of colonial apartheid, through its colonial dispossession project, made sure that whites were "generationally" advantaged at the expense of blacks (Lephakga 2012a, 65-80, 2013, 379-400; 2015, 95-148). This generational advantage is linked to the colonial dispossession project, which can be traced to the 1600s (Biko 2004, 96-108; Lephakga 2012a, 65-80; 2013, 379-400; 2015, 95-148; Pheko 1986, 1-92). The colonial dispossession project ${ }^{5}$ was institutionalised through, among other things, the dispossession of land, the Balkanisation of South Africa and the alienation of black people through different legal acts (Biko 2004, 88-95; Lephakga 2012b, 65-80; 2013, 379-400; 2015, 36-93; Pheko 1986, 148-159). It is for this reason, Lephakga argued, that: "Racial discrimination (although it existed before) was made an official policy by the National Party after they came into power in 1948. The National Party passed the Group Act in 1950 to further the aims of [colonial] Apartheid (or Separate Development - Hendrik Verwoerd's ideology)" (Lephakga 2012b, 40). This Act further Balkanised South Africa (Biko 2004, 88; Lephakga 2012b, 65; 2013, 379; 2015, 36; Pheko 1986, 148). As a result, most of the country was declared a "White Group Area" and all non-whites who owned property or lived in these white areas were expropriated and forced to move to their respective Group Areas (Biko 2004, 88-95; 96-108; Lephakga 2012b, 65-80; 2013, 379-400; 2015, 36-93; Pheko 1986, 1-92). "This policy was used to relocate both urban and rural non-whites" (Lephakga 2012a, 22). Due to this relocation the majority of South Africans were forced to live in the Bantustans (homelands), which economically alienated them. As a result of this, Balkanisation resulted in the institutionalisation of poverty among blacks (Biko 2004, 96-108; Lephakga 2012b, 65-80; 2013, 379-400; 2015, 36-93; Pheko 1986, 1-92).

5 The idea behind the terminology of "colonial dispossession project" is captured well by Pheko $(1986,1)$ when he notes that "South Africa is a black man's country. It was ruled by indigenous Africans. It was free and independent. The arrival of Jan van Riebeeck on 6 April 1652 started the dispossession of the African people. The history of South Africa which followed is a tragic story of military suppression, political oppression, economic exploitation and social degradation of a people, unprecedented in the history of the civilised world." Therefore, "colonial dispossession project" refers to the colonial commitment of dispossessing African people of their land, being, economy, etc. 
It is further argued in this paper that the colonial policies of the National Party, or the colonial apartheid government, which were finally sealed with the policy of the establishment of the Bantustans or homelands, made sure that Africans became aliens in South Africa and to the economy; as a result they were designated to be generationally poor (Biko 2004, 96-108; Lephakga 2012b, 56-77; Terreblanche 2002, 371-406). The epistemological foundation(s) and justification(s) of the establishment of the homelands or Bantustans followed the same epistemological foundation and justification as colonisation. Fanon $(1963,29-34)$ rightly noted that the colonial world or colonies were divided into two, namely the settlers' towns, which were beautiful and well fed, and the native towns, which were inhumane. Fanon $(1963,30)$ captured this well when he argued that "the settlers' town is a well-fed-town, an easy-going town; its belly is always full of good things. The settlers' town is a town of white people, of foreigners". On the other hand Fanon $(1963,30)$ captured the situation in the native town as "belonging to the colonised people... a place of ill fame". The settlers' town is beautiful and well fed for a particular reason: to maintain the supremacy of the colonisers and so the colonised or conquered can look at the settlers' town in awe (Biko 2004, 88-95, 96-108; Fanon 1963, 38-42). The idea behind this division is to further institutionalise the colonial division of the world and to foster social death among the colonised and conquered; hence the establishment of homelands or Bantustans. Fenwich and Rosenhain (1991, 77) argued that:

All Africans were declared to belong to one of the 10 Bantustans, with native language and tribal origins as the deciding factor. In this way, Africans were deprived of citizenship of South Africa and instead became citizens of the designated homeland. Thus, they had no place or rights in South Africa, but were simply regarded as migrant workers who, if unemployed, had to return to their Bantustan. The old, the young, and the dependent wives were "sent-back" to the Bantustans and whole communities living in South Africa (in the black-spots) were therefore forcibly uprooted and relocated.

It is also imperative to further note that the Bantustans or homelands were underdeveloped with no proper infrastructure; they were economically poor and as a result disadvantaged those living there (Biko 2004, 88-95; Terreblanche 2002, 371-406). The situation in the Bantustans was similar, if not worse, to the Fanonian "native town". For Fanon the native town is a world without spaciousness; men live there on top of each other and their huts are built one on top of the other. This is a hungry town, starved of bread, of meat, of shoes, of coal, of light. This town is also a crouching village, a town on its knees, a town wallowing in the mire (Fanon 1963, 30). Agriculture in the homelands or Bantustans became rather impossible. Hence, those living there, that are the colonised and conquered, had to leave the homelands to look for economic opportunities in the then white South Africa. This had a terrible impact upon the communal structure of families as families were broken due do this "job seeking movement". For this reason Biko $(2004,91)$ argued that: 
Economically, the blacks have been given a raw deal. Generally speaking the areas where Bantustans are located are the least developed in the country, often very unsuitable either for agricultural or pastoral work. Not one of the Bantustans have access to the sea and in all situations mineral rights are strictly reserved for the South African government. In other words Bantustans only have rights extending to 6 feet below surface of the land.

It is furthermore argued in this paper that the colonial apartheid ${ }^{6}$ policy, which was the main architecture of the impoverishment of the blacks in South Africa, was based on a colonial policy of divide and rule. This policy is founded on the colonial principles of gaining and maintaining power by breaking up larger concentrations of power into pieces that individually have less power than the one implementing the strategy. It is further based on the colonial strategy of breaking up existing power structures, preventing smaller groups from linking up, causing rivalries and fomenting discord among people (Biko 2004, 88-95, 96-108; Fanon 1963, 38-42; Stewart 1957, 49-57). This colonial policy was institutionalised in South Africa through land dispossession, Balkanisation and politicisation of the ethnicity of the colonised and conquered people (Mamdani 1996, 5). As a result of this colonial policy, the black conquered people were divided and even alienated from their ancestral land and thus the colonial apartheid system was able to rule over the majority of the people of South Africa (Biko 2004, 88-95, 96-108; Lephakga 2012b, 65-80; 2013, 379-400; 2015, 36-93; Mamdani 1996, 5; Pheko 1986, 1-92).

The division and alienation resulted in the internalisation of oppression and selfhate by black people (Asante and Hall 2011, 1-24). Hence, white people were able to rule over them as they doubted their humanness (Asante and Hall 2011, 107-134). This was done with policies which were aimed at alienating black people from their ancestral and mother land. Accordingly Pieterse $(2001,47)$ argued:

First there was the Group Area Act, which was passed by Parliament in 1950. The Act was considerably modified and strengthened by the Group Act (77 of 1957), the Group Act Amendment Act (1957) and the Group Areas Amendment Act (1961). And as a result of these Acts, it was practically impossible for black people to migrate from their homelands to the cities where the jobs were. They were condemned to a subsistence economy in remote rural communities.

6 "Apartheid, was its goal: not just to separate the races, but to segregate them, each into their own housing, school, shops, restaurants, beaches, even cemeteries. In South Africa, the black majority would not be citizens, but merely migrant workers, because each tribe would be given its own homeland and eventually its own independent black state. Marriages and sexual relationships between races would be illegal. Colored and Indian people could not be given their own lands, but would have their suburbs, beaches, schools, shops etc. They would not vote for parliament as the whites did, but would be listed on separate voters' rolls to vote for Colored and Indian Assemblies. Blacks, because they were not citizens of South Africa, would not be able to vote at all. This made necessary a system of racial classification, judged largely by appearance and racial origin." (Fenwich and Rosenhain 1991, 59-60). 
The colonial apartheid system cannot be divorced from the problems of poverty that we have in the present South Africa. It created a system where black people were exploited, suppressed, oppressed and humiliated. This resulted in the impoverishment of black people. Terreblanche $(2002,26)$ argued that "we cannot avoid the conclusion that unemployment, poverty, inequality, violence and criminality are not only serious problems that mainly affect black South Africans, but also that they have an indisputable structural or systematic character. All of these problems have been shaped and 'created' over a very long period by the power structures on which the systems of colonialism, segregation, and apartheid were based". Thus, the true trace of poverty in South Africa cannot be divorced from the 1913 Land Act. This law was passed in order to dispossess the majority of South Africans of their land (Biko 2004, 88-95, 96-108; Lephakga 2012b, 65-80; 2013, 379-400; 2015, 36-93; Pheko 1986, 1-92). This law had a terrible impact upon the well-being, economy and identity of those who were dispossessed of their land. Land is central to African people and it is everything for them (Lephakga 2012b, 56-77). Land is a place, a space where people can trace their beingness, which is deeply rooted in the land. More importantly, land is food for African people. It is where they plant and live. Fenwich and Rosenhain $(1991,52)$ thus argued that:

This law was known as the "law of dispossession", because it was designed to force blacks to become part of the labour market by denying them the right to own land. This law had a tremendous effect on black people, because the land which was their source of life was taken away from them. This caused economic dependence. [Economic dependence in this regard refers to the dependence of black people on white people.] With the establishment of this law, the status of black people changed from being owners into being workers or slaves. This law provided for the establishment of native reserves amounting to 7.3 per cent of the total land area. At this time, nearly 70 per cent of the total population was black, so the reserves were not large enough to support that number of people. With this Act Africans could no longer own farms other than within reserves and any African owning land was forced to sell it to a white buyer or it was taken by force.

The growing incarnation of poverty among African people in South Africa was further manifested through the establishment of the Bantu Education policy. This policy was sealing the apartheid government's ideal dream of segregation and inequality. It was established to further manifest the ideology of segregation of people in South Africa on the bases of economy, gender and race. Those who became passengers of this policy were destined for a segragationalist and inferior economy, which resulted in the majority of the people in South Africa being "generationally" poor. Thus Biko (2004, 74) once argued: "The most potent weapon in the hands of the oppressor is the mind of the oppressed." This education system made sure that the majority of South Africans would be generationally destined to live under impoverished conditions. According to Fenwick and Rosenhain $(1991,74)$ :

The major thrust of government policy to do with black education was to centre it in the Bantustans and to abolish education facilities for blacks in "white" areas. The curriculum 
was designed to prepare students for life in the Bantustans and in the less skilled areas of the white economy. There was heavy emphasis on tree-planting, soil conservation and agricultural practice, religion, hygiene and local customs. Mother tongue instruction was initiated, where the tribal language of the Bantustans was the teaching language for primary school, with English and Afrikaans taught as second language. After the age of six, Afrikaans and English were used as the teaching language. Government attempts to force students to be taught in Afrikaans lead to riots in Soweto in 1976.

The uniqueness of poverty in South Africa is that black people are mostly the victims of this long-standing establishment of poverty by the colonial apartheid system. This system had a terrible impact on black people; it resulted in poverty becoming "a daily bread or a daily communion" for generations of black people. With the dawn of democracy black people had hoped that they would be liberated from the dungeons of poverty. Instead, they realised that the democracy we had attained in South Africa was not an economic democracy; it became a constitutional democracy which gave black people a right to vote. It did not address the problems caused by the apartheid system. The exploitative system of colonial apartheid, which resulted in the impoverishment of many blacks in South Africa, created "a people" who are disturbed, exploited and psychologically fearful. Hence Biko $(2004,86)$ argued: "Powerlessness breeds a race of beggars who smile at the enemy and swear at him in the sanctity of their toilets."

The newly elected government of a democratic South Africa inherited the problems of the past which were caused by the apartheid system. Hence, we see black people becoming poor and poorer every day in the present South Africa. Terreblanche (2002, 25) argues that:

When, in 1994, a democratically elected government came to power, it inherited a contradictory legacy: the most developed economy in Africa on the one hand, and major socio-economic problems on the other. The most serious of these are high rates of unemployment; abject poverty among more than 50 per cent of the population; sharp inequalities in the distribution of income, property and opportunities; and high levels of crime and violence. What makes these problems so pressing is the fact that it is mostly blacks - and especially Africans - who are at the receiving end.

\section{NEO-LIBERAL TRANSITION TO DEMOCRACY AND ITS MAINTENANCE OF POVERTY AMONG BLACKS}

The negotiated settlement in South Africa has been hailed worldwide as a political miracle (Lephakga 2015, 95-143; Stevens et al 2006, 293-312; Terreblanche 2002, 27). It was seen as a combination of ends and means. The prevailing assumption was that the transition would come only after further bitter strife and bloodshed (Barber 2009, 5171; Cronin 1994, 1-39; Lephakga 2015, 95-148; Mamdani 2013, 1-28; Terreblanche 2002, 27). Thus, when there was a peaceful transition it was seen as a "political miracle" (Barber 2009, 51-71; Cronin 1994; Lephakga 2015, 95-148; Mamdani 2013, 1-28; Terreblanche 2002, 25-47). 
The political miracle unleashed pent-up expectations of social justice and a dramatic improvement in the living conditions of blacks (Lephakga 2015, 95-143; Terreblanche 2002, 25-47). However, following Lephakga's argument, it served as a political "smokescreen" to protect the economic powers that be (Lephakga 2015, 95-148; Terreblanche 2002, 25-47). The negotiated settlement resulted, in line with the colonial project, in the conquerors receiving their first prize, namely economic power, while the conquered received their first prize, namely political power under constitutional democracy (Lephakga 2015, 95-148; Terreblanche 2002, 51-89). Thus, Lephakga (2015, 95-148) argues that the negotiated settlement was a neo-liberal transition to democracy.

The neo-liberal approach to a transition to democracy operates under the pseudoassumption that political power comes first and that the rest shall follow automatically (Cronin 1994, 1-39; Lephakga 2015, 95-148; Terreblanche 2002, 51-89). This should be understood against the backdrop of the following (Cronin 1994, 1-39; Lephakga 2015, 95-148; Mamdani 2013, 1-28; Terreblanche 2002, 51-89):

- The sudden interest of the National Party (NP) and the business sector in South Africa in a negotiated settlement in the late 1980s.

- The fall of the Soviet Union 1989-1990/5.

- The shift in the thinking of the African National Congress (ANC) in the period 1989-1995.

It is the contention of this paper, following Terreblanche (2002, 51-89) and Lephakga (2015, 95-148), that the sudden interest of the National Party (NP) and the business sector in South Africa was not accidental.

It is imperative to note, following the continual nature of the colonial project (of being continuous and also of always finding new survival and accumulative strategies), that, on the one hand the accumulative economic strategy of the NP and business sector of South Africa had failed in the late 1980s, and as a result they were in need of a new accumulative strategy; and on the other hand their political power was in disarray as a result of internal and external pressures (Cronin 1994, 1-39; Lephakga 2015, 95148; Mamdani 2013, 1-28; Terreblanche 2002, 51-89). Thus it must be mentioned that, as a result of the then economic policies of the colonial apartheid government, the maintenance of the homelands, the states of emergency and sanctions, the economy of South Africa was in disarray (Cronin 1994, 1-39; Lephakga 2015, 95-148; Mamdani 2013, 1-28; Terreblanche 2002, 51-89). As a result of all these, both the NP and the business sector in South Africa were in dire need of an accumulative solution or strategy (Cronin 1994, 1-39; Lephakga 2015, 95-148; Mamdani 2013, 1-28; Terreblanche 2002, 51-89).

The late 1980s, with cracks starting to show within the Soviet Union, served as a ripe time to opt for a negotiated settlement because there was growing resistance within the Third World countries against all authoritarian regimes, like the NP in South Africa (Cronin 1994, 1-39; Lephakga 2015, 95-148; Mamdani 2013, 1-28; Terreblanche 
2002, 51-89). Thus, the West, following the colonial imposition of the centre (which is occupied by Europeans) on the periphery (which is occupied by non-Europeans) had to find a new strategy in order to continue having their hands in the economy of Third World countries such as South Africa. Hence, 1989-1995 was a ripe period for a new accumulative strategy for the West and functionaries, namely authoritarian regimes like the NP in South Africa (Cronin 1994, 1-39; Lephakga 2015, 95-148; Mamdani 2013, 1-28; Terreblanche 2002, 51-89). Therefore, the cracks and eventually the fall of the Soviet Union in the period 1989-1995 served as a ripe time to influence all Third World countries to opt for a transition to democracy. This is because the fall of the Soviet Union meant that the war between socialism and capitalism had ended and capitalism had emerged as a victor. Therefore, the West proposed to the Third World countries to opt for democracy because the alternative, which is socialism, had collapsed (Cronin 1994, 1-39; Lephakga 2015, 95-148; Mamdani 2013, 1-28; Terreblanche 2002, 51-89).

This article emphasises and concurs with other authors, that as a result of the fall of the Soviet Union, the African National Congress (ANC) was forced to have a shift in their thinking (Cronin 1994, 1-39; Lephakga 2015, 95-148; Mamdani 2013, 1-28; Terreblanche 2002, 51-89) because the fall of the Soviet Union left the ANC in disarray. A "shift in their thinking" in this regard refers to their commitment to a socialist strategy of nationalisation for the benefit of the people (Lephakga 2015, 95-148; Terreblanche 2002, 51-89). The ANC could no longer sustain their military camps, which were heavily funded by the Soviet Union, and thus lost their military bargaining power; their economic policies were based to a large extent on the socialist economic policies as held by the Soviet Union (Cronin 1994, 1-39; Lephakga 2015, 95-148; Mamdani 2013, 1-28; Terreblanche 2002, 51-89). Thus, the NP and the business sector in South Africa took this opportunity to economically dupe the ANC. Both the NP and the business sector in South Africa approached the ANC and engaged them in their economic policies, which were largely socialist. Following this, the NP and the business sector in South Africa, through the West, influenced the ANC to abandon their economic policies; they did this by convincing them that socialistic economic policies are not practical and that they have led to the fall of the Soviet Union (Cronin 1994, 1-39; Lephakga 2015, 95-148; Terreblanche 2002, 51-89). It was at this stage that both the NP and the business sector in South Africa pushed the elite compromise. This compromise meant that the NP and the business sector in South Africa would get their first prize in the negotiations, namely economic power, and the ANC and its constituency would get their first prize, namely political power under constitutional democracy (Cronin 1994, 1-39; Lephakga 2015, 95-148; Terreblanche 2002, 51-89). The ANC at this stage operated under a pseudopolitical assumption, namely "seek first political power and then the rest will follow" (Lephakga 2015, 95-148; Terreblanche 2002, 51-89).

It is imperative to note that, as a result of growing political instabilities within the Third World countries and as a result of the fall of the Soviet Union, the West influenced the Third World countries to opt for a transition to democracy (Cronin 1994, 1-39; Lephakga 2015, 95-148; Mamdani 2013, 1-28; Terreblanche 2002, 51-148). This 
transition was a neo-liberal transition to democracy under capitalism (Cronin 1994, 1-39; Lephakga 2015, 95-148; Terreblanche 2002, 51-148). Thus Lephakga (2015, 107), following Lenin, notes that, a transition to democracy under capitalism is like "freedom in [a] capitalist society [which] always remains about the same as it was in Ancient Greek republics: Freedom for slave owners."

It is significant to mention that democracy is not the problem but the interpretation thereof within the capitalist system is. The issue here is that democracy under capitalism changes nothing but instead becomes a new accumulative strategy for the same people. Thus, Terreblanche $(2002,16)$ correctly notes that the logic of democracy and capitalism is contradictory. While on the one hand democracy emphasises joint interests, equality, and common loyalties, capitalism on the other hand is based on self-seeking inequality and conflicting individual and group interests (Lephakga 2015, 95-148; Terreblanche 2002, 51-89). It is further contradictory in that "the legal system that protects both democracy and capitalism is based on the principle of equality before the law", but maintains inequalities in the distribution of property rights and opportunities in the capitalist system (Lephakga 2015, 95-148; Terreblanche 2002, 51-89). Terreblanche (2002, 16-17) correctly captures the contradictory logic of democracy and capitalism when he argues that "the logic of capitalism - given the unequal freedoms and unequal rights upon which is based - thus goes against the grain of the logic of democracy".

It must be re-iterated that the "neo-liberal" transition to democracy under capitalism does not translate to socio-economic justice but instead maintains the socio-economic order (Lephakga 2015, 95-148; Terreblanche 2002, 51-89). Democracy under capitalism emphasises that economic participation will be determined by competition and markets under the free market capitalistic system. This logic of democracy under capitalism simply means that "capitalism attempts to maximise efficiency and profit through merciless competition in a free market system in which the strong, skilful, and property owners win, and the less cunning lose" (Lephakga 2015, 95-148; Terreblanche 2002, 51-89).

\section{CONCLUSION}

It is argued in this paper that poverty among the blacks in South Africa was engineered and institutionalised to further feed into the colonial epistemological foundation(s) and justification(s) that the colonised and conquered are non-beings. The colonial epistemological foundation(s) and justification(s) are based on the division of the world into two, namely the centre (which is occupied by Europeans who are Beings with a capital letter B) and the periphery (which is occupied by non-Europeans who are non-beings). As a result of this division the centre feels justified to impose itself on the periphery through colonisation. The centre sees colonisation as a process of being guardians of the colonised and conquered, who happen to be non-beings. The colonised and conquered are impoverished, on the one hand to maintain the supremacy of the coloniser and conquerors, and on the other hand to maintain the subservient status of 
the colonised and conquered. It is further argued that the colonial apartheid system institutionalised poverty among blacks through land dispossession, Balkanisation and politicisation of the ethnicity of the colonised and conquered. It is also argued that the neo-liberal transition to democracy was not for the purpose of transforming the inclusive socio-economic system, which systematically excluded blacks, but was for the purpose of coming up with a new accumulative strategy for the economic powers that be.

\section{REFERENCES}

Asante, M. K. and Hall, R. E. 2011. Rooming in the Master's House: Power and Privilege in the Rise of Black Conservatism. London: Paradigm Publishers.

Barber, J. 2009. "South Africa's Political Miracle: The International Dimension." South African Journal of International Affairs 7 (1), 11 Nov: 51-71.

Biko, S. 2004. I write what I like. Johannesburg: Picador Africa.

Bond, P. 2000. Elite Transition: From Apartheid to Neoliberalism in South Africa. Pietermaritzburg: University of Natal Press.

Cronin, J. 1994. "Sell-out, or the Culminating Moment? Trying to make Sense of the Transition," History Workshop at the University of Witwatersrand, 13-17 July.

Dussel, E. 1985. Philosophy of Liberation. Maryknoll, NY: Orbis Books.

Fanon, F. 1963. The Wretched of the Earth. London: Penguin Books.

Fenwick, J. and Rosenhain, C. 1991. South Africa: From Settlement to Self-Determination. Oxford: Oxford University Press.

Kitto, H. D. F. 1951. The Greeks. Australia: Penguin Books.

Lembede, A. M. 1996. Freedom in our Lifetime: The Collected Writings of Anton Muziwakhe Lembede. Ohio University Press.

Lephakga, T. 2012a. Reclaiming God and Reclaiming Dignity: The History and Future of Black Liberation from Internalised Oppression. Studia Historiae Ecclesiasticae 38 (2), December: 65-80.

Lephakga, T. 2012b. The Significance of Justice for True Reconciliation on the Land Question in the Present Day South Africa. Master's thesis, University of South Africa, Pretoria.

Lephakga, T. 2013. "The History of Theologised Politics in South Africa, The 1913 Land Act and its Impact on the Flight from the Black Self." Studia Historiae Ecclesiasticae 39 (2), December: 379-400.

Lephakga, T. 2015. "Dealing Lightly with the Wounds of my People: A Theological Ethical Critique of the South African Truth and Reconciliation Commission." Unpublished DTh thesis, University of South Africa, Pretoria. 
Maldonado-Torres, N. 2007. On the Coloniality of Being: Contribution to the Development of a Concept. Cultural Studies 21 (2-3), March/May: 240-270.

Mamdani, M. 1996. "Reconciliation without Justice." Southern African Review of Books, 46, Nov/Dec: $3-5$.

Mamdani, M. 2013. Beyond Nuremberg: The historical Significance of the Post-Apartheid Transition in South Africa. Unpublished Annual Inaugural Lecture delivered at the Mapungubwe Institute for Strategic Reflection University of Witwatersrand, 18 March.

Mudimbe, V. Y. 1988. The Invention of Africa: Gnosis, Philosophy, and the Order of Knowledge. Indianapolis: Indiana University Press.

Patterson, O. 1982. Slavery and Social Death. Cambridge (USA): Harvard University Press.

Pheko, M. 1986. Apartheid: The Story of a Dispossessed People. London: Marram Books.

Pieterse, H. J. C. 2001. Preaching in the Context of Poverty. Pretoria: University of South Africa.

Ramose, R. B. 1999. African Philosophy through Ubuntu. Harare, Zimbabwe: Mond Books Publishers.

Sinclair, T. A. 1962. Aristotle: The Politics. New York: Penguin Books.

Sobukwe, R. 1959. Speeches of Mangaliso Sobukwe, 1949-1959: and other documents of the PanAfricanist Congress of Azania, PAC of Azania Office of the Chief Representative to the US and the Caribbean (1978).

Stevens, G., Franchi, V., and Swart, T. 2006. A Race Against Time: Psychology and Challenges to Deracialisation in South Africa. Pretoria: Unisa Press.

Steward, N. 1957. "Divide and Rule: British Policy in Indian History." Science and Society 15 (1): 49-57.

Terreblanche, S. 2002. A History of Inequality in South Africa: 1652-2002. Pietermaritzburg: University of Natal Press. 